\title{
ІСТОРІЯ УКРАЇНСЬКОГО ТЕАТРУ, ВИМІРЯНА ЙОГО ЛЕКСИКОЮ ВІД ПОЧАТКІВ ДО СОНЯЧНОГО ЦАРСТВА (Історико-методологічні нотатки)
}

У статті розглянуто можливості дослідження історії термінів і понять як маркера історії театру, театральної свідомості й театральної культури в ціілому. Виявлено переломні моменти в історії термінології театру в Украӥні.

Ключові терміни: історія театральних термінів і понять, індуктивний і дедуктивний методи, «канон шедеврів», історія театральної культури.

В статье рассмотрены возможности исследования истории терминов и понятий как маркера истории театра, театрального сознания и театральной культуры в целом. Выявлены переломные моменты в истории терминологии театра в Украине.

Ключевые термины: история театральныхх терминов и понятий, индуктивный и дедуктивный методы, «канон шедевров», история театральной культуры.

The article examines the possibilities of history of terms and concepts as a marker of the history of the theater, theatrical consciousness and theatrical culture in general studying. The turning points in the history of the terminology of the theater in Ukraine are revealed.

Key terms: history of theatrical terms and concepts, inductive and deductive method, "canon of masterpieces», history of theatrical culture.

Джерела й одиниці аналізу, ознаки, на які спирається у своїй праці дослідник, - це маркери, котрі розсекречують його метод, виявляючи подеколи підміну театрознавчого аналізу ідеологемами (на кшталт «високохудожній»), а у хронічних випадках - навіть даючи змогу передбачити результат дослідження.

Писана історія театру - літературоцентрична, адже спирається здебільшого на літературні тексти - на рецензії, тобто особисті враження свідків, які фіксують: деякі достеменні факти (лише частина яких має історичну вартість); свідомо або несвідомо перекручені факти (перетворені внаслідок цих операцій на нефакти); забарвлені суб'єктивним смаком естетичні оцінки; гарно аргументовані та погано мотивовані точки зору; коментарі до неіснуючих подій (аберації пам'яті, «наснилося»); інтерпретаиії вірогідних фактів тощо. Свідчення ці аналізуються зазвичай вибірково й упереджено (приміром, до «справи» Леся Курбаса досі не долучено показання свідків з іншого боку - Д. Грудини, М. Семенка, автора статті, приписуваної Г. Юрі та ін.). Тому в історії, котра спирається на рецензії, домінують вигуки і зойки на кшталт «гарно», «добре», «вдало» тощо [16].

Надто довірливе ставлення до рецензій (фіксації особистих смаків), з одного боку, й ігнорування матеріальних джерел, з іншого, призвело, зрештою, до відмови від фактів на користь зрадливих «точок зору», ідеологем і т. ін. Адже, спираючись на такі сумнівні свідчення, історія зазвичай потрапляє у полон джерел, створених талановитими (отже, заразливими!) свідками, і реалізується у низці пропагандистських процедур: встановлення взірців, формування канону видатних творів, рецензування минулого. Оскільки ж кількість «геніїв», «видатних», «визначних», «талановитих» і просто «обдарованих» в історії мистецтва обмежена, дослідникові минулого залишається лише одне 3 двох: або здійснювати «відкриття» і створювати нових «геніїв», або «поглиблювати» пізнання освячених творів і митців, які вже входять до канону. Незалежно від вибору, обидва шляхи ведуть у глухий кут, адже обрана для аналізу ознака у такому разі завжди матиме ситуативний характер і залежатиме від революційної доцільності та панівних смаків (понад 
сто років тому Володмир Перетц закликав «поставити питання про те, що таке “художне”» $\mathrm{i}$ “чи має воно абсолютне значення?”» $[23,33])$.

Разом із тим, і досі незайманим залишається корпус джерел, які ще у XIX столітті створили передумови для народження наукової істоpiї театру і дослідження яких було покладено в основу класичних праць про античний театр (В. Дерпфельд, В. Латишев, Б. Варнеке та ін.), а згодом і театру середньовіччя; і саме ці джерела визначили особливості методу, запропонованого Максом Геррманном та його наступниками; йдеться про пам'ятки матеріальної культури (архітектура, археологія, іконографія, «історія речей»). Адже й досі такі джерела, як афіші, фотокартки, аудіо- і відеозаписи вивчаються недостатньо і залишаються поза увагою дослідників; навіть якщо ми не можемо відмовитися від рецензій, то досліджуються вони здебільшого як правдиві свідки і посередники між виставою й істориком, а не як самостійний об'єкт, який здатен багато чого повідомити про театральну культуру минулого.

Коли все так просто, то чим визначено схиляння до того або іншого типу джерел і вибір між матеріальною культурою і рецензією на користь останньої?

Це схиляння зумовлено домінуванням одного $з$ двох підходів - дедуктивного або індуктивного, тобто залежністю або незалежністю від системи панівних поглядів, концепцій і забобонів, а головне - від політичної історії та iї періодизації (мовляв, зміна політичної системи відразу веде до змін театральної культури; насправді, ці процеси, як можна переконатися на досвіді незалежної України, тривають дуже довго і не завжди помітні неозброєним оком).

Дедуктивна історія театру спирається на заздалегідь визначений «канон шедеврів мистеитва», підтверджуючи його, пояснюючи, аргументуючи й інтерпретуючи, прикрашаючи його дедалі вишуканішими й вишуканішими епітетами, немов здійснюючи танець з бубнами навколо свого ідола.

Індуктивній історії - все це (або майже все) - байдуже, бо їі цікавлять не видатні постаті і шедеври, а театральна культура у иілому, і не їі оцінка, а особливості. А це, у свою чергу, означає, що вона орієнтується не на виключне, а на повсякденне, нормальне, звичайне; тобто на феномен культури, а не на шедеври. Посутньо, це те, до чого закликали і Олексій Гвоздєв («популярна п’єса - бойовик теа- тру - має для історії театру набагато більше значення, ніж трагедія прославленого драматурга 3 неабиякими літературними чеснотами» $[4,85])$, і Петро Рулін («історія театру цікавить нас не так своїми національними формами, як найтиповішими й найвистиглішими зразками, що вона в ту чи іншу добу втворила» $[22,16])$.

Отже, найперше питання (якщо нас цікавлять «найтиповіші зразки», а не поповнення «канону шедеврів») - де, в чому, як, у яких джерелах $i$ схованках, якими інструментами і методами відшукувати типові сліди театральної культури?

Серед методологічних резервів, призабутих внаслідок свідомого викорінення точних методів дослідження, слід виокремити актуальні у зарубіжному театрознавстві: історію технічних винаходів і відкриттів, історію повсякдення, історію понять і уявлень, формальний аналіз, дискурс-аналіз, іконографічний метод, контент-аналіз, інституціональний метод та інші.

Одним із інструментів, який, поряд 3 iншими, може допомогти розв'язати низку питань 3 історії театру, є Iсторія термінів (нім. Begriffsgeschichte) - напрям досліджень, який дістав поширення у 1960-х роках - передусім завдяки зусиллям Райнгарта Козеллека [7; 20; 21]. Цей напрям, врешті, став цілком логічною відповіддю практиків на репліку Людвіга Вітгенштайна: «межі моєї мови означають межі мого свіму». [2, 70]. Плідність цього підходу обгрунтовував свого часу Ганс-Георг Гадамер у праці «Історія понять як філософія» [3], а практичні можливості використання довели дослідники у різних галузях. Цю ж проблему усвідомлюють автори праці з історії поетики [5], повторюючи на різний лад надзвичайно актуальну тезу про те, що більша частина icmoричних термінів і понять поетики, увійшовши y підсвідоме мистеитвознавства і забувши свої біографії, все ж продовжуе керувати нашими оцінками, міркуваннями, а врешті, й методологією. Адже має рацію Славой Жижек, коли пише: «Боротьба за ідеологічно-політичну гегемонію - це завжди боротьба за привласнення термінів, які "самі по собі" сприймаються як “аполітичні”, так, що ніби перебувають за рамцями політики» [6, 66-67]. Це означає, що за змінами театральної лексики, появою нових і переосмисленням старих термінів можна виявити особливості театральної практики i, головне, особливості театральної культури, а подеколи навіть поставити під сумнів чинні пері- 
одизації і характеристики театру тієї або іншої доби. Цей метод дає змогу розв'язати не лише питання історії, а й змінити погляд на явища сучасного театру: якщо система термінів залишається незмінною впродовж майже двох століть, чи не свідчить це про те, що, незважаючи на біг часу, потяг стоїть на місці?

Навіть поверховий огляд корпусу джерел 3 історії українського театру XVII - початку ХІХ століть $[9 ; 10 ; 11 ; 12 ; 13 ; 14 ; 15 ; 16 ; 17 ; 18$; 19] дає можливість виявити деякі «вузькі місця» i «дисонанси» у нашому сприйнятті театральної минувшини.

Найперше, що впадає в око у процесі аналізу термінів театральної культури означеного періоду, - домінування слухача, а не глядача: «Епиліог благодарствует благоразумному слишателю за приліжное слишаніе»; «молим слишателей о внимателное в дійстві слишание»; «соизвол, слишателю, раченим внимати Страсть побіду Христову будем изявляти»; «пролог слишателю дійствія изволь послушати»; «к оному нашему дійствію вашого слу$x a$ и доброхотства требуем»; «при гарній грі "Простака" - слухач не втерпить, щоб не реготатися»; «вона [“Наталка Полтавка"] невгамовно лунає на сцені і буде лунать довго-довго, бо вона ще жде свого настоящого слухача - селянина, для котрого й написана» і т. ін. Це означає, що до кінчя ХІХ століття глядач (слухач) був налаштований переважно на слуховисько, а не на видовисько. Це нібито суперечить висновкам Володимира Перетца про величезну кількість сценічних ефектів в українському шкільному театрі [24]. Однак суперечить лише на перший погляд, що пояснює приклад оперної вистави: або слухати і дивитися, або тільки слухати - цей вибір залежить не лише від постановки, а й від самого відвідувача театру.

Усупереч уявленню про нормативність шкільної драми XVII століття, ні ії діячі, ні навіть театральні діячі першої половини XIX століття ще не висувають жорстких вимог до театру, не погрожують авторам і виконавцям санкціями. Говорячи про театр, вони у цей час здебільшого вживають терміни «забава», «забавка» і навіть «забава иерковна». Саме про забаву розповідає і Квітка-Основ'яненко, коли описує передумови організації театру у Харкові: «С приездом нового начальника у нас все одушевились < .. > . Начались в Харькове балы, маскарады, благородные собрания, называвшиеся тогда “клубами”» $[8,91]$. Розвиток нових форм громадського спілкування веде до організації театру, про «естетичні завдання» якого Квітка писав у такому самому напівграйливому-напівглузливому тоні: «Между прочими заведениями для веселости и рассеяния устроен был театр» $[8,90]$.

На противагу першій половині XIX століття у 1860-х роках «найпрогресивніші», «передові» сили суспільства почали висувати вимоги, формувати канони, накидати театрові художні та ідейні завдання («правдивість», «ідейність», «художність»), котрі у майже незмінному вигляді залишалися актуальними і на початку XX століття. Однак поки що це відбувається на тлі стрімкої динаміки термінів, пов'язаних із визначенням самої сфери мистецької діяльності («артизм», «іскуство», «художство», «штука») і нечуваного розмаїття жанрових визначень («ігри комедіальні», «сумогляд», «забавка домовая», «трагедія любовна», «трагедія з плясками»).

Особливо помітними термінологічні зміни стають, коли зіставляємо напівграйливі театральні тексти Г. Квітки-Основ'яненка та С. Гребінки 3 «ідейними» текстами авторів 1860-х років, а надто з текстами кінця XIX ст., далі 3 новою лексикою Миколи Вороного i, нарешті, - 3 практикою театру «соціалістичного реалізму», котра, відкидаючи мистецькі уявлення початку XX століття, канонізувала терміни і поняття (отже, критерії і прийоми) реалістичного мистецтва середини XIX століття. Щоправда, одночасно із «привласненням» досвіду реалістичного мистецтва, взявши на себе утримання театру, держава запропонувала і нові умови, що, здається, стало несподіванкою для митців, котрі, орієнтуючись на романтичний ідеал творчості, у своїй повсякденній праці ще не мали звички брати у розрахунок побажань замовника.

«Привласнивши» театр, держава, за сприяння самих митців, стала формувати нові жанри громадського життя і відповідну войовничу риторику, котра пронизала театральну культуру: «барикади театральні», «барикади театру», «боротьба з театром», «кампанія політична театру», «політика театральна», «культфронт», «політком», «фронт культурний», «фронт театральний», «штаб режисерський» (ці ж ідеї у м'якішій, прихованій формі реалізувалися у формі «дискусій мистецтвознавчих» і «диспутів театральних», «змагань соціалістичних», «конкуренції театрів» і навіть «стахановського руху» на теренах театру). 
Ставши власністю держави («націоналізація» й «удержавлення» театру, «облік робітників мистецтв»), театр цілком органічно було підпорядковано відповідним формам контролю: державному апаратові («комісаріат мистецтва», «міністерство преси і пропаганди», «наркомосвіта», «репертком», «управа видовищних підприємств»); мистецькій громадськості («громадськість літературна», «рада театральна», «рада художня», «рада художньо-політична», «нарада драматургічна», «нарада театральна», «теа-нарада»); новим формам опікування митцем («допомога політично-художня», «меценат», «меценатство», «шеф», «шефство») і виховання кадрів - «мистецьких марксистських кадрів», «кадрів режисерів» і т. ін.

Об'єднавши митців у спілку («спілка професійна працівників мистецтва»), держава визначила їхні завдання («стандартизація театру», «обслуговування», «виховання» і «перевиховання глядача», «будівництво театральне», «відродження театру», «агітація», «пропаганда»), спрямовані на «фабрикування театральних постановок» - «культурної», «мистецької», «художньої» «театральної продукції», котра б спиралася на відповідні «стандарти театральні».

Звісно, не всі митці однаково справлялися 3 поставленим завданням. Отож у процесі виховання до них стали застосовувати як засоби заохочення («артист заслужений», «артист народний», «гонорар», «грамота для театру», «звання почесне», «чин» - саме так початково називалися почесні звання), так і засоби покарання. До порушників, згідно з прейскурантом адміністративних i кримінальних злочинів у сфері мистецтва (від «не до кінця розкрив тему» - до «контрреволюція у мистецтві»), застосовувалися відповідні форми покарань, аж до відлучення від тіла влади і конфіскації ліцензії на життя.

Адміністративна мудрість підказувала, що до покарань краще залучати сторонніх осіб. Так було актуалізовано інститут «критики» 3 іiі новим інструментарієм - «колективними рецензіями» та іншими, здавалося б, опосередкованими формами впливу влади на театр. Палкими учасниками цього процесу стали «споживачі» - не всі, звісно, адже «дрібнобуржуазна» i «міщанська публіка» до уваги не бралася, «соціальне замовлення» пов'язувалося, головним чином, із «обслуговуванням» «масового», «робітничого», «селянського», «організованого глядача», якого, 3 одного боку, примушували купувати «абонементи», здійснювати «культвилазки» і «культпоходи», «закуповувати вистави», а $з$ іншого, саме його голос ставав вирішальним під час «колективних рецензій», «глядацьких конференцій», «обговорення вистав»; більше того, саме цього глядача «організовували», «виховували», «перевиховували» і т. ін. Врешті це призвело до того, що митець, спокутуючи свої гріхи, неначе флагелянт, змушений був влаштовувати публічне самобучкування: він «визнавав» і «виправляв» свої «помилки й огріхи», «політичні пороки», пов'язані зі створенням «ідеологічно шкідливих проявів», «збоченнями ідеологічними» і «культивуванням безідейності». Це публічне дійство дістало назву «самокритики».

Убезпечити себе від «помилок» було практично неможливо, чим і визначалася зручність ситуації для влади і постійне відчуття небезпеки для митця. Ця подвійність забезпечувалася блискучою, зовні дуже схожою на термінологію, риторикою, лексика якої мала майже символічний характер і могла наповнюватися необмеженим змістом: для схвальної оцінки - «високохудожнє», «геніальний твір», «високі досягнення художні», «висока вартість культурна», «висока вартість театральна», «значення п’єси актуальне», «значення художнє», «мистецтво будуче», «мистецтво високе і живе», «мистецтво справжнє», «митець революційний», «правда соціальна», «режисери передові», «режисер-новатор», «стиль радянський», «стиль реалістичний»; для критики — «антихудожнє», «аполітичність», «безідейність», «безпринциповість художня», «відрив театру від пролетарської авдиторії», естетика - «буржуазна», «мистецтво попутницько-балаганне», «несмак», «репертуар дешевий», «тенденція антихудожня», «форма мистецька буржуазна», «форма театру буржуазна» та ін. Коли фантазії не вистачало, переходили на конкретні мистецькі явища («культура шароварна», «мистецтво хуторянське», «гопакедія», «гопакомедія») й особи («курбалесія», «курбасизм», «курбасіада», «курбасівщина»), демонізуючи беззахисного митця в очах пересічного глядача. Серед риторичних прийомів поза конкуренцією були «реалізми», з приводу кількості яких глузували і Остап Вишня, і Юрій Смолич: реалізм «експресивний», «класово-войовничий», «монументальний», «психологічний», «старий», «театральний», «умовний»... і нарешті «соціалістичний». 
Відтак і загальнородове поняття «театр» вже перестає задовольняти; на зміну морфологічним уявленням XIX століття у лексиці 19201930-х років фіксується понад півтори сотні неологізмів на кшталт «театр агітації», «театр виробничий», «театр виробничо-експериментальний», «театр європейський», «театр європеїзаторський» та ін. Почесне місце серед них посідали, звісно ж, театри, для характеристики яких уживалися синоніми: «пролетарський», «пролетарської диктатури», «професіональний», «радянський», «реалістичний», «реалістичного стилю», «реалістично-психологічний», «революційний», «робітничий», «робітничо-селянський», «соціалістичний», «справжній», «художньо-реалістичний»... Отже «справжній» i «високохудожній» — це те саме, що й «реалістично-психологічний».

Борсаючись між цими берегами, митці змушені були брати участь у перегонах (тобто у соціалістичному змаганні), виборюючи право на звання «головного», «зразкового», «показового», «провідного» або «центрального» театру. Цілком логічно процес рейтингування завершився беатифікацією одних і відлученням від тіла влади інших — «художників-пачкунів», які створювали «сумбур замість музики», не бажали "рушити по новому шляху, що веде в сонячне царство радянського мистецтва» [25, 39] i, покірно сидячи на валізах, очікували на обшуки, зізнання, заслання і розстріли.

Зрозуміло, усі ці «зовнішні» обставини позначалися і на системі понять, котрі фіксували методи роботи режисера й актора, адже саме у цей час - i у практиці театру, і у театральній критиці стає обов'язковим ідейно-тематичний корпус («тема», «ідея», «конфлікт», «правда»). Показово, що з трьох термінів «реалізм», «правда художня» і «натуральність», котрі у XIX столітті сприймалися як синоніми, «реалізм» в Україні фіксується найпізніше. Спочатку, у 1860-х роках, дістають популярність терміни «натуральність» («Грав <..> найстаранніше $<\ldots>$, однако ж < ..> не завадило б трохи більше натуральности»; «грав місцями натурально, 3 правдою і гумором»; «діалоги розвиваються тут логічно, натурально і свобідно»; «гра пана М. Г. не зовсім добра - бо не натуральна»; «натуральніші рухи»; «натуральне, правдиво видно в комедії»; «міг він бути більш натуральним, а не скарикатурованим»; «діялоги розвиваються ту логічно, натурально і свобідно»; «она так естественна»; «натуральність» [18,
177]), «правда» $i$ «правдивість» («Як всі твори українські, так і сеся драма повна життя і правди»; «не входячи іще в питання, наскілько в цілій мелодрамі правди историчної»; «правдиві артисти»; «нема в ній [п’єсі] за порошину поезії, ані психологічної правди, нема в ній внутренного розвою події» $[18,215])$. І лише від 1890-х років - у текстах М. Вороного, Л. Старицької-Черняхівської, І. Стешенка та інших — фіксується «реалізм» $[18,230]$.

Здавалося б, ось підстави гучно відсвяткувати майже півторасторічний переможний ювілей правди, реалізму та ідейності в украӥнському mеатрi. Однак, застерігав Дмитро Антонович, «це не був реалізм у сучасному розумінні того слова, це не був натуралізм двадцятого віку, але це був побут і реалізм, як його розуміли в вісімдесятих роках і якого від театру бажали» $[1,132]$.

Так само й миле нашому серцеві поняття «ідейності», котре лише ледь починає формуватися у XIX столітті, і терміни-привиди на кшталт «художній», «високохудожній», «антихудожній», історико-етимологічні зміни яких демонструють перетворення з синоніма «мистецтва» і «належного сфері мистецтва» на естетичний зашморг для конкурентів та інакомислячих.

Аж ось іще один аспект, який також заслуговує на увагу у контексті вимірювання історії українського театру його лексикою.

Як перетинаються чинні періодизації українського театру, запропоновані I.Франком, I. Стешенком, П. Руліним, Г. Лужницьким, Р. Пилипчуком та іншими дослідниками, зі змінами його лексики, чи відображають чинні періодизації зміни театральної культури і театральної свідомості? Що таке, скажімо, театр корифеїв - надзвичайно успішний мистецький проект чи подія, котра змінила саму театральну культуру, систему ії уявлень і понять, отже й термінів?

3 огляду на завдання й обсяг пропонованої розвідки автор залишає ці запитання поки що без відповіді. Тим більше, що вже настав час повернутися до репліки Людвіга Вітгенштайна, якого вже автор цитував: «межі моєї мови означають межі мого світу» [2, 70]. Театральну культуру також замкнено у межах мови.

Щоб зрозуміти історичну природу цих «обмежень», достатньо здійснити очуження, подумки перенісши якесь мистецьке явище у систему термінів (отже, у театральну культуру) 
іншої доби. Приміром, уявити театр корифеїв, який працює в умовах «соціального замовлення», «обслуговування масового глядача», «культпоходів», «колективних рецензій», «глядацьких конференцій» й «обговорення вистав». Уявити, як корифеї «визнають» i «виправляють» свої «помилки й огріхи», «політичні пороки», пов'язані зі створенням «ідеологічно шкідливих проявів», «збоченнями ідеологічними» i «культивуванням безідейності». Хоч наскільки б химерним видавався цей експеримент, він недалеко відійшов від дійсності. Адже саме такими були особливості театральної культури 1920-х років, у якій показували свої вистави М. Садовський і П. Саксаганський. Культури, для якої цілком прийнятною i, можливо, навіть зрозумілою була подібна фанфарна тарабарщина: «Безупинна, незважаючи на окремі помилки, боротьба театру <...> за революційний пролетарський світогляд, за високохудожнє подання в сценічному мистецтві актуальних і передових ідей та образів соціалістичної дійсності, за розкриття нової людини, - все це було могутньою передумовою культурно-мистецького зростання театру» [26, 27].

Упродовж останніх десятиліть світ, здається, дуже змінився. Однак, незважаючи на це, навколо і досі чутно радянську лексику: заклики до «виховання глядача», до «правди», «ідейності» і т. ін. А балачки про «духовність» наштовхують на думку, що їх механічно було перенесено із матеріалів XXVII з'їзду КПРС, де, між іншим, ця лексема фігурує понад п'ятдесят разів - приблизно з такою самою частотою як і у сьогоднішніх маніфестах.

Що означають ці збіги і розбіжності між новим світом, який поглинає нас, і незмінно-войовничою, неначе замовляння, системою понять, котра цупко тримає нас у минулому? Про що сигналізує ця симптоматика? Про те, що театральна культура, зручно облаштувавшись у сонячному царстві, опинилася в уявному світі, якого вже давно не існує? Якщо одні й ті самі слова можуть наповнюватися різним змістом, чи не означає це, що вони вже остаточно втратили своє значення і використовуються лише як порожні ритуальні замовляння?

Однак культура ніколи не буває цілісною в ідеальному розумінні. Цілісність іï - у суперечностях, в одночасності смерті і народження, натхненних закликів до «європейський цінностей» і звички затуляти пельку опонентові з позиції сили або, ще краще, пафосної демагогії.
Бо зміни культури - у зміні свідомості і реалій, а не гасел.

\section{Джерела та література}

1. Антонович Д. Триста років українського театру. 16191919 / Д. Антонович. - Прага: Укр. громад. видавничий фонд, 1925. - 242 c.

2. Вітгенштайн Л. Tractatus logico-philosophicus. Фiлософські дослідження ; пер. 3 нім. Є.Поповича / Л. Вітгенштайн. - К. : Основи, 1995. - 312 с.

3. Гадамер Г.-Г. История понятий как философия // Гадамер Г.-Г. Актуальность прекрасного / Г.-Г. Гадамер. - М. : Искусство, 1991. - 368 с.

4. Гвоздев А. Итоги и задачи научной истории театра // Задачи и методы изучения театра. Сб. - Л., 1924.

5. Европейская поэтика от античности до эпохи Просвещения : Энциклопедический путеводитель. - М. : изд-во КУЛАГИНОЙ-INTRADA, 2010. - 512 c.

6. Жижек С. Почему «типична» мать-одиночка? // Жижек С. Итерпассивность. Желание: влечение. Мультикультурализм. - СПб., 2005. - С. 66-67.

7. История понятий, история дискурса, история менталитета: сб. ст.[пер. с нем.] / Под ред. Х. Э. Бёдекера. - М. : Новое литерат. обозрение, 2010. - 328 с.

8. Квітка-Основ'яненко Г.История театра в Харькове // Квітка-Основ'яненко Г. Зібрання творів у 7 т. - К. : Наукова думка, 1981. - Т. 7. - 640 с.

9. Клековкін О. До історії театральної термінології в Україні кінця XVI - початку XIX ст. // Український театр. 2008. 一 № 6 .

10. Клековкін О. До історії театральної термінології в Україні XIX - початку XX ст. (спостереження на матеріалі п'єс, публіцистичної й епістолярної спадщини I. К. Карпенка-Карого) // Науковий вісник / Київськ. нац. універс. театру, кіно і телебачення ім. І. К. Карпенка-Карого. - К., 2010. - Вип. 6.

11. Клековкін О. Марко Кропивницький: лексика театру // Актуальні проблеми мистецької практики і мистецтвознавчої науки / Мистецькі обрії’ № 3 (12): Альманах : Науково-теоретичні праці та публіцистика / Академія мистецтв України. — К. : АМУ, 2010.

12. Клековкін О.Межі театру (проблеми термінологіі) // Український театр. - 2008. - № 3.

13. Клековкін О.Морфологія театру (до історії термінів) // Міст. Мистецтво, історія, сучасність, теорія : Зб. наук. пр. 3 мистецтвознавства і культурології / ІПСМ НАМ України. - К., 2010. — Вип. 7.

14. Клековкін О. Режисура: до історії термінів // Мистецтвознавство України. Збірн. наук. праць. Вип. 10. — К., 2010.

15. Клековкін О. Структура драми: до історії термінів // Актуальні проблеми мистецької практики і мистецтвознавчої науки / Мистецькі обрії’ № 2 (11): Альманах : Науково-теоретичні праці та публіцистика / Академія мистецтв України. - К., 2009.

16. Клековкін О. Техніка класичної розправи // Сучасні проблеми дослідження, реставрації та збереження культурної спадщини: Зб. наук. праць з мистецтвознав., архітектурознавства і культурології / ІПСМ НАМ України. - К., 2014. - Вип. 10.

17. Клековкін О. Українські сценічні старожитності / Матеріали до словника XI - початку XX ст. / Записки Наукового Товариства імені Шевченка. Том CCLXII. Праці театрознавчої комісії. - Львів, 2011.

18. Клековкін О. Theatrica / Українські старожитності. XVI - початок XX ст. : Матеріали до словника / Інститут проблем сучасного мистецтва НАМ України. — К., 2011. 
19. Клековкін О. Theatrica / Фабрика видовиськ: Лексика українського театру 1917-1930-х років. Матеріали до словника / ІПСМ НАМ України. - К., 2013.

20. Козеллек Р. Минуле майбутнє. Про семантику історич. часу ; пер. 3 нім. / Райнгард Козеллек. - К. : Дух і літера, 2005. $-380 \mathrm{c}$.

21. Козеллек Р. Часові пласти: Дослідження з теорії історії ; пер. 3 нім. / Райнгард Козеллек. - К. : Дух і літера, 2006. - $436 \mathrm{c}$.

22. Рулін П. Переднє слово // Варнеке Б. Античний театр / П. Рулін. - Х.-К., 1929.

23. Перетц В. Из лекций по методологии истории русской литературы. История изучений. Методы. Источники. Корректурное издание на правах рукописи. - К., 1914.

24. Перетц В. Театральні ефекти в старовинному театрі // Україна. - 1926. - Кн. 1.

25. Проти формалізму і «лівацької потворності» в мистецтві. - Комсомольская правда. - 14. 02. 1936 // Проти формалізму, натуралізму і спрощенства в мистецтві: Зб. - К., 1936.

26. Савченко Я. П'ятнадцять років театру імені Ів. Франка / Я. Савченко. — К. : Мистецтво, 1935. — 54 с.

\section{References}

1. Antonovych, D. Trysta rokiv ukrayins'koho teatru. 16191919. - Praha, 1925.

2. Vithenshtayn, L. Tratstatus logitso-philosophitsus. Filosofs'ki doslidzhennya. - K., 1995.

3. Hadamer, H.-H. Ystoryya ponyatyy kak fylosofyya // Hadamer H.-H. Aktual'nost' prekrasnoho. — M., 1991.

4. Hvozdev, A. Ytohy y zadachy nauchnoy ystoryy teatra // Zadachy y metody yzuchenyya teatra. - L., 1924.

5. Evropeyskaya poetyka ot antychnosty do epokhy Prosveshchenyya: Entsyklopedycheskyy putevodytel'. M., 2010.

6. Zhyzhek, S.Pochemu «typychna» mat'-odynochka? // Zhyzhek S.Yterpassyvnost'. Zhelanye: vlechenye. Mul'tykul'turalyzm. - SPb., 2005. - S. 66-67.

7. Ystoryya ponyatyy, ystoryya dyskursa, ystoryya mentalyteta: Sb. st. / Pod red. Kh. E. Bedekera. - M., 2010.

8. Kvitka-Osnov'yanenko, H. Ystoryya teatra v Khar'kove // Kvitka-Osnov'yanenko H.Zibrannya tvoriv u 7 t. $-\mathrm{K}$. 1981.

9. Klekovkin, O.Do istoriyi teatral'noyi terminolohiyi v Ukrayini kintsya XVI - pochatku XIX st. // Ukrayins'kyy teatr. - 2008. - \# 6 .

10. Klekovkin, O.Do istoriyi teatral'noyi terminolohiyi v Ukrayini XIX - pochatku XX st. (sposterezhennya na materiali p'yes, publitsystychnoyi y epistolyarnoyi spadshchyny I. K. Karpenka-Karoho) // Naukovyy visnyk /
Kyyivs'k. nats. univers. teatru, kino i telebachennya im. I. K. Karpenka-Karoho. - K., 2010. - Vyp. 6.

11. Klekovkin, O.Marko Kropyvnyts'kyy: leksyka teatru // Aktual'ni problemy mystets'koyi praktyky i mystetstvoznavchoyi nauky / Mystets'ki obriyi' \# 3 (12): Al'manakh: Naukovo-teoretychni pratsi ta publitsystyka / Akademiya mystetstv Ukrayiny. - K.: AMU, 2010.

12. Klekovkin, O. Mezhi teatru (problemy terminolohiyi) // Ukrayins'kyy teatr. 一 2008. — № 3 .

13. Klekovkin, O. Morfolohiya teatru (do istoriyi terminiv) // Mist. Mystetstvo, istoriya, suchasnist', teoriya: Zb. nauk. pr. z mystetstvoznavstva i kul'turolohiyi / IPSM NAM Ukrayiny. - K., 2010. - Vyp. 7.

14. Klekovkin, O. Rezhysura: do istoriyi terminiv // Mystetstvoznavstvo Ukrayiny. Zbirn. nauk. prats'. Vyp. 10. - K.: AMU, 2010

15. Klekovkin, O.Struktura dramy: do istoriyi terminiv // Aktual'ni problemy mystets'koyi praktyky i mystetstvoznavchoyi nauky / Mystets'ki obriyi'\# 2(11): Al'manakh: Naukovo-teoretychni pratsi ta publitsystyka / Akademiya mystetstv Ukrayiny. - K., 2009.

16. Klekovkin, O.Tekhnika klasychnoyi rozpravy // Suchasni problemy doslidzhennya, restavratsiyi ta zberezhennya kul'turnoyi spadshchyny: Zb. nauk. prats' z mystetstvoznav., arkhitekturoznavstva i kul'turolohiyi / IPSM NAM Ukrayiny. K., 2014. - Vyp. 10.

17. Klekovkin, O. Ukrayins'ki stsenichni starozhytnosti / Materialy do slovnyka XI - pochatku XX st. / Zapysky Naukovoho Tovarystva imeni Shevchenka. Tom SSLXII. Pratsi teatroznavchoyi komisiyi. — L'viv, 2011.

18. Klekovkin, O. Theatritsa / Ukrayins'ki starozhytnosti. XVI - pochatok XX st.: Materialy do slovnyka / Instytut problem suchasnoho mystetstva NAM Ukrayiny. - K., 2011.

19. Klekovkin, O. Theatritsa / Fabryka vydovys'k: Leksyka ukrayins'koho teatru 1917-1930-kh rokiv. Materialy do slovnyka / IPSM NAM Ukrayiny. - K., 2013.

20. Kozellek, R. Mynule maybutnye. - K., 2005.

21. Kozellek, R. Chasovi plasty : Doslidzhennya $\mathrm{z}$ teoriyi istoriyi. - K., 2006.

22. Rulin, P. Perednye slovo // Varneke B. Antychnyy teatr. Kh.-K., 1929.

23. Peretts, V.Yz lektsyy po metodolohyy ystoryy russkoy lyteratury. Ystoryya yzuchenyy. Metody. Ystochnyky. Korrekturnoe yzdanye na pravakh rukopysy. - K., 1914.

24. Peretts, V.Teatral'ni efekty v starovynnomu teatri // Ukrayina. - 1926. - Kn. 1

25. Proty formalizmu i «livats'koyi potvornosti» v mystetstvi. Komsomol'skaya pravda. - 14.02.1936// Proty formalizmu, naturalizmu i sproshchenstva v mystetstvi: Zb. - K., 1936.

26. Savchenko, Ya. P'yatnadtsyat' rokiv teatru imeni Iv. Franka. - K., 1935. 